\title{
Permanent Dentition of Children with Congenital Rubella Syndrome
}

\author{
Moriyoshi Murakami, Atsushi Rokutanda and Rei Ito \\ Department of Anatomy (Chief : Prof. Hiroshi Yamada) \\ Tomio Iha, Masatoshi Kawano, Makoto Nishioka and Yuzo Natori \\ Department of Preventive Dentistry (Chief : Prof. Eiichi Saeki) \\ Kyushu Dental College, Kitakyushu, Japan . \\ Received December 20th, 1978.
}

\section{Introduction}

An Australian ophthalmologist, Dr. Gregg (1941) ${ }^{1)}$, reported the cataract and heart defects in children whose mothers had rubella in their early pregnancy. Since then, many children with various congenital disturbances due to rubella have been born and it present a worldwide social problem. In Japan, rubella wasepidemic in Okinawa in 1964 and 1965 when many pregnant mothers were infected and many children with congenital rubella syndrome were born. There have been many disturbances reported as congenital rubella syndrome of which major signs are shown in table $1 .{ }^{2-14}$ ) There are few reports on teeth. Delayed eruption of teeth in children with congenital rubella syndrome was reported by Cooper, et al. (1969) ${ }^{7)}$, Sakugawa (1976) 10), etc.. They mentioned the deciduous dentition and no report has been found on the permanent dentition. Authors investigated the permanent dentition of children with congenital rubella syndrome in detail and the results are in this report.

Table 1 Predominant clinical findings in children with C R S
Low birth weight ${ }^{3-6,101}$
Cardiac defects ${ }^{2-10}$ )
Eye defects ${ }^{2}, 4-10$ )
Deafness $\left.{ }^{3,6}, 7,9,10\right)$
Mental defects $\left.{ }^{2}, 3,9,10\right)$
Purpura ${ }^{4-7)}$
Hepatosplenomegaly ${ }^{3-6}$ )
Bulging anterior fontanelle $e^{4,5,8)}$
Jaundice ${ }^{3,6)}$
Microcephaly $\left.{ }^{3}, 11,12\right)$
Micrognathia ${ }^{6,8,11-13)}$
Delayed dentition ${ }^{10,14}$
Cleft palate ${ }^{6}$ )
Malformed teeth ${ }^{2}$

\section{Materials and Methods}

The investigation was conducted in early August, 1977. A hundred and four children (55 males and 49 females) with congenital rubella syndrome were investigated. They were born between February, 1965 and January, 1966 and were attending a class 
for children with hearing difficulty, which was located in the middle south of Okinawa Island centered in Naha city.

Besides the detailed oral examination, plaster models of the upper and lower dental arches and panoramic radiographs were taken. After examining these data, the condition of tooth eruption and kinds of teeth were identified. Teeth of which crowns are partially exposed are recognized as being erupted.

As control groups, school children of the same age as the children with congenital rubella syndrome were selected. They consisted of 20 males and 22 females and they

Table 2 Incidences of eruption and non-eruption of permanent teeth and anodontia

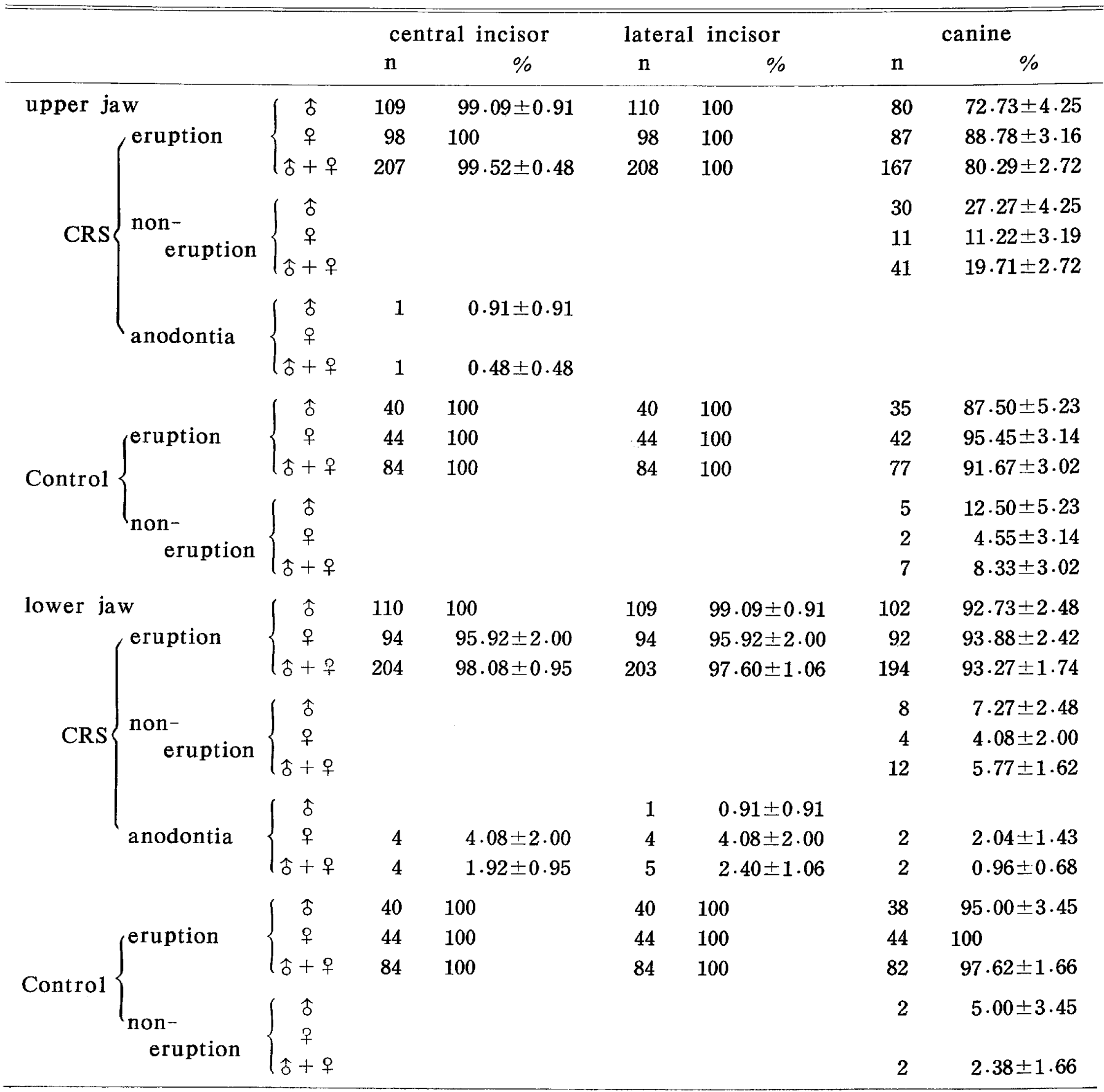


were attending usual class in the same area. Oral examination was done and plaster models of the upper and lower dental arches were taken.

In comparison between values, $\mathrm{D} \geqq 2$ diff. is considered significant.

\section{Results}

Table 2 shows the incidences of eruption and non-eruption of the permanent teeth and anodontia in the children with congenital rubella syndrome (hereinafter abbrevia-

in the children with congenital rubella syndrome and control groups

\begin{tabular}{|c|c|c|c|c|c|c|c|}
\hline \multicolumn{2}{|c|}{ 1st premolar } & \multicolumn{2}{|c|}{ 2nd premolar } & \multicolumn{2}{|c|}{ 1st molar } & \multicolumn{2}{|c|}{ 2nd molar } \\
\hline $\mathrm{n}$ & $\%$ & $\mathrm{n}$ & $\%$ & $\mathrm{n}$ & $\%$ & $\mathrm{n}$ & $\%$ \\
\hline 106 & $96 \cdot 36 \pm 1.79$ & 86 & $78 \cdot 18 \pm 3.94$ & 110 & 100 & 26 & $23.64 \pm 4.05$ \\
\hline 94 & $95.92 \pm 2.00$ & 77 & $78 \cdot 57 \pm 4 \cdot 15$ & 98 & 100 & 41 & $41.84 \pm 4.98$ \\
\hline 200 & $96 \cdot 15 \pm 1.33$ & 163 & $78 \cdot 37 \pm 2.85$ & 208 & 100 & 67 & $32 \cdot 21 \pm 3.24$ \\
\hline 4 & $3.64 \pm 1.79$ & 24 & $21.82 \pm 3.94$ & & & 84 & $76.36 \pm 4.05$ \\
\hline 4 & $4.08 \pm 2.00$ & 21 & $21 \cdot 43 \pm 4 \cdot 15$ & & & 56 & $57.14 \pm 5.00$ \\
\hline \multirow[t]{2}{*}{8} & $3.85 \pm 1.33$ & 45 & $21.63 \pm 4.85$ & & & 140 & $67 \cdot 31 \pm 3 \cdot 25$ \\
\hline & & & & & & $\begin{array}{l}1 \\
1\end{array}$ & $\begin{array}{l}1.02 \pm 1.01 \\
0.48 \pm 0.48\end{array}$ \\
\hline 38 & $95.00 \pm 3.45$ & 33 & $82.50 \pm 6.01$ & 40 & 100 & 20 & $50.00 \pm 7.91$ \\
\hline 42 & $95.45 \pm 3.14$ & 37 & $84.09 \pm 5.51$ & 44 & 100 & 28 & $63.64 \pm 7 \cdot 25$ \\
\hline 80 & $95.24 \pm 2.32$ & 70 & $83.33 \pm 4.07$ & 84 & 100 & 48 & $57.14 \pm 5.40$ \\
\hline 2 & $5.00 \pm 3.45$ & 7 & $17.50 \pm 6.01$ & & & 20 & $50.00 \pm 7.91$ \\
\hline 2 & $4.55 \pm 3 \cdot 14$ & 7 & $15.91 \pm 5.51$ & & & 16 & $36 \cdot 36 \pm 7.25$ \\
\hline 4 & $4.76 \pm 2.32$ & 14 & $16.67 \pm 4.07$ & & & 36 & $42 \cdot 86 \pm 5.40$ \\
\hline 99 & $90.00 \pm 2.86$ & 73 & $66.36 \pm 4.50$ & 107 & $97.27 \pm 1.55$ & 47 & $42.73 \pm 4.72$ \\
\hline 91 & $92.86 \pm 2.60$ & 78 & $79.59 \pm 4.07$ & 96 & $97.96 \pm 1.43$ & 63 & $64 \cdot 29 \pm 4.84$ \\
\hline 190 & $91.35 \pm 1.95$ & 151 & $72.60 \pm 3.09$ & 203 & $97.60 \pm 1.06$ & 110 & $52.88 \pm 3.46$ \\
\hline 11 & $10.00 \pm 2.86$ & 37 & $33.64 \pm 4.50$ & & & 63 & $57 \cdot 27 \pm 4.72$ \\
\hline 7 & $7 \cdot 14 \pm 2 \cdot 60$ & 19 & $19.39 \pm 3.99$ & & & 34 & $34.69 \pm 4.81$ \\
\hline \multirow[t]{4}{*}{18} & $8.65 \pm 1.95$ & 56 & $26.92 \pm 3.08$ & & & 97 & $46 \cdot 63 \pm 3.46$ \\
\hline & & & & 3 & $2.73 \pm 1.55$ & & \\
\hline & & 1 & $1.02 \pm 1.01$ & 2 & $2.04 \pm 1.43$ & 1 & $1.02 \pm 1.01$ \\
\hline & & 1 & $0.48 \pm 0.48$ & 5 & $2.40 \pm 1.06$ & 1 & $0.48 \pm 0.48$ \\
\hline 33 & $82.50 \pm 6.01$ & 35 & $87.50 \pm 5.23$ & 40 & 100 & 36 & $90.00 \pm 4.74$ \\
\hline 41 & $93.18 \pm 3.80$ & 36 & $81.82 \pm 5.81$ & 44 & 100 & 31 & $70.45 \pm 6.88$ \\
\hline 74 & $88 \cdot 10 \pm 3.53$ & 71 & $84.52 \pm 3.95$ & 84 & 100 & 67 & $79.76 \pm 4.38$ \\
\hline 7 & $17.50 \pm 6.01$ & 5 & $12 \cdot 50 \pm 5 \cdot 23$ & & & 4 & $10.00 \pm 4.74$ \\
\hline 3 & $6 \cdot 82 \pm 3 \cdot 80$ & 8 & $18 \cdot 18 \pm 5 \cdot 81$ & & & 13 & $29.55 \pm 6.88$ \\
\hline 10 & $11.90 \pm 3.53$ & 13 & $15.48 \pm 3.95$ & & & 17 & $20 \cdot 24 \pm 4.38$ \\
\hline
\end{tabular}


ted as CRS) and of the Control groups.

\section{Central Incisor}

CRS children : In the maxillae, the rate of eruption is $99.09 \%$ for the males, $100.00 \%$ for the females, and $99.52 \%$ for the total of males and females. In the mandibles, the rate of eruption is $100.00 \%$ for the males, $95.92 \%$ for the females, and $98.08 \%$ for the total of males and females. Non-eruption was not found in either jaw. The rate of anodontia is $0.91 \%$ for the male maxillae and $4.08 \%$ for the female mandibles. There is no sex difference or jaw difference.

Control children: The rate of eruption is $100.00 \%$ for the either jaw of males and females.

There is no significant difference between the CRS and Control children.

\section{Lateral Incisor}

CRS children : In the maxillae, the rate of eruption is $100.00 \%$ for the males and females. In the mandibles, the rate of eruption is $99.09 \%$ for the males, $95.92 \%$ for the females, and $97.60 \%$ for the total of males and females. Non-eruption was not found in either jaw. The rate of anodontia is $0.91 \%$ for the male mandibles, $4.08 \%$ for the female mandibles, and $2.40 \%$ for the total of males and females. There is no sex difference or jaw difference.

Control children: The rate of eruption is $100.00 \%$ for the males and females in either jaw.

There is no significant difference between the CRS and Control children.

\section{Canine}

CRS children : In the maxillae, the rate of eruption is $72.73 \%$ for the males, $88.78 \%$ for the females, and $80.29 \%$ for the males and females. There is a sex difference and the males showed lower rates. In the mandibles, the rate of eruption is $92.73 \%$ for the males, $93.88 \%$ for the females, and $93.27 \%$ for the total of males and females. There is no sex difference. There is a jaw difference in the males and in the total, with the maxillae showing lower rates. In the maxillae, the rate of non-eruption is $27.27 \%$ for the males, $11.22 \%$ for the females, and $19.71 \%$ for the total of males and females. In the mandibles, the rate of non-eruption is $7.27 \%$ for the males, $4.08 \%$ for the females, and $5.77 \%$ for the total of males and females. The rate of anodontia is $2.04 \%$ for the female mandibles.

Control children : In the maxillae, the rate of eruption is $87.50 \%$ for the males, $95.45 \%$ for the females, and $91.67 \%$ for the total of males and females. In the mandibles, the rate of eruption is $95.00 \%$ for the males, $100.00 \%$ for the females, and $97.62 \%$ for the total of males and females. There is no sex or jaw difference.

There is a significant difference in the rate of canine eruption between the CRS and Control children in terms of the males and total maxillae, with the CRS children showing lower rates.

\section{First Premolar}


CRS children : In the maxillae, the rate of eruption is $96.36 \%$ for the males, $95.92 \%$ for the females, and $96.15 \%$ for the total of males and females. In the mandibles, the rate of eruption is $90.00 \%$ for the males, $92.86 \%$ for the females, and $91.35 \%$ for the total of males and females. In the maxillae, the rate of non-eruption is $3.64 \%$ for the males, $4.08 \%$ for the females, and $3.85 \%$ for the total of males and females. In the mandibles, the rate of non-eruption is $10.00 \%$ for the males, $7.14 \%$ for the females, and $8.65 \%$ for the total of males and females. Anodontia was not found. There is no sex difference or jaw difference.

Control children : In the maxillae, the rate of eruption is $95.00 \%$ for the males, $95.45 \%$ for the females, and $95.24 \%$ for the total of males and females. In the mandibles, the rate of eruption is $82.50 \%$ for the males, $93.18 \%$ for the females, and $88.10 \%$ for the total of males and females. There is no sex difference or jaw difference.

There is not a significant difference between the CRS and Control children.

\section{Second Premolar}

CRS children : In the maxillae, the rate of eruption is $78.18 \%$ for the males, $78.57 \%$ for the females, and $78.37 \%$ for the total of males and females. In the mandibles, the rate of eruption is $66.36 \%$ for the males, $79.59 \%$ for the females, and $72.60 \%$ for the total of males and females. There is a sex difference with the males showing lower rates. The rate of non-eruption is $21.82 \%$ for the males, $21.43 \%$ for the females, and $21.63 \%$ for the total of males and females, in the maxillae. The rate of anodontia is $1.02 \%$ for the female mandibles.

Control children : In the maxillae, the rate of eruption is $82.50 \%$ for the males, $84.09 \%$ for the females, and $83.33 \%$ for the total of males and females. In the mandibles, the rate of eruption is $87.50 \%$ for the males, $81.82 \%$ for the females, and $84.52 \%$ for the total of males and females. There is no sex difference or jaw difference.

When comparing the second premolar eruption rate between the CRS and Control children, there is a significant difference in terms of the male mandibles and total mandibles, with the CRS children showing lower rates.

\section{First molar}

CRS children : In the maxillae, the rate of eruption is $100.00 \%$ for the males and females. In the mandibles, the rate of eruption is $97.27 \%$ for the males, $97.96 \%$ for the females, and $97.60 \%$ for the total of males and females. Non-eruption was not found. The rate of anodontia is $2.73 \%$ for the males, $2.04 \%$ for the females, and $2.40 \%$ for the total of males and females, in the mandibles. There is no sex difference or jaw difference.

Control children : The rate of eruption is $100.00 \%$ for the either jaw_of males and females.

There is no significant difference between the CRS and Control children. 


\section{Second Molar}

CRS children : In the maxillae, the rate of eruption is $23.64 \%$ for the males, $41.84 \%$ for the females, and $32.21 \%$ for the total of males and females. There is a sex difference with the males showing a lower rate. In the mandibles, the rate of eruption is $42.73 \%$ for the males, $64.29 \%$ for the females, and $52.88 \%$ for the total of males and females. There is a sex difference with the males showing a lower rate. There is a jaw difference with the maxillae showing lower rates. In the maxillae, the rate of non-eruption is $76.36 \%$ for the males, $57.14 \%$ for the females, and $67.31 \%$ for the total of males and females. In the mandibles, the rate of non-eruption is $57.27 \%$ for the males, $34.69 \%$ for the females, and $46.63 \%$ for the total of males and females. The rate of anodontia is $1.02 \%$ for the female maxillae.

Control children : In the maxillae. the rate of eruption is $50.00 \%$ for the males, $63.64 \%$ for the females, and $57.14 \%$ for the total of males and females. In the mandibles, the rate of eruption is $90.00 \%$ for the males, $70.45 \%$ for the females, and $79.76 \%$ for the total of males and females. In the mandibles, there is a sex difference with the males showing higher rates.

When comparing the second molar eruption rates between the CRS and Control children, there are significant differences in the maxillae of the males and females, and in the mandibles of the males, with the CRS children showing lower rates than the Control children.

\section{Discussion}

The authors investigated the permanent dentition of children with congenital rubella syndrome (12 years old, 55 males and 49 females) who reside in Okinawa. The following is a summarized discussion about the results.

The congenital rubella syndrome is the congenital anomaly caused by the infection of rubella virus through placental blood stream in early pregnancy. That this congenital anomaly is related to the corresponding phases of rubella virus infection and embryonic development of the organs has been reported ${ }^{2,7,10)}$. Moore (1974) ${ }^{15}$ ) described the correlation between environmental factors and congenital malformations in the Fig. 1, showing the sensitive phase to the malformation induction. In terms of teeth, it is most sensitive between the late sixth week and early eighth week of pregnancy and is influenced up to the 16 th week. Langman (1969) ${ }^{16}$ ) stated that the malformation of teeth is induced when infected by rubella between the sixth to ninth week of pregnancy. The developmental phase of a tooth bud is the sixth week to three months in utero ${ }^{17,18)}$ and this approximately corresponds to the phase when tooth buds are susceptible to the disturbance as described in the figure by Moore $(1974)^{15}$. Hearing disturbances can be caused between the 4 th to 16 th week in utero. Although it is not certain exactly when the pregnant mothers of the children with 


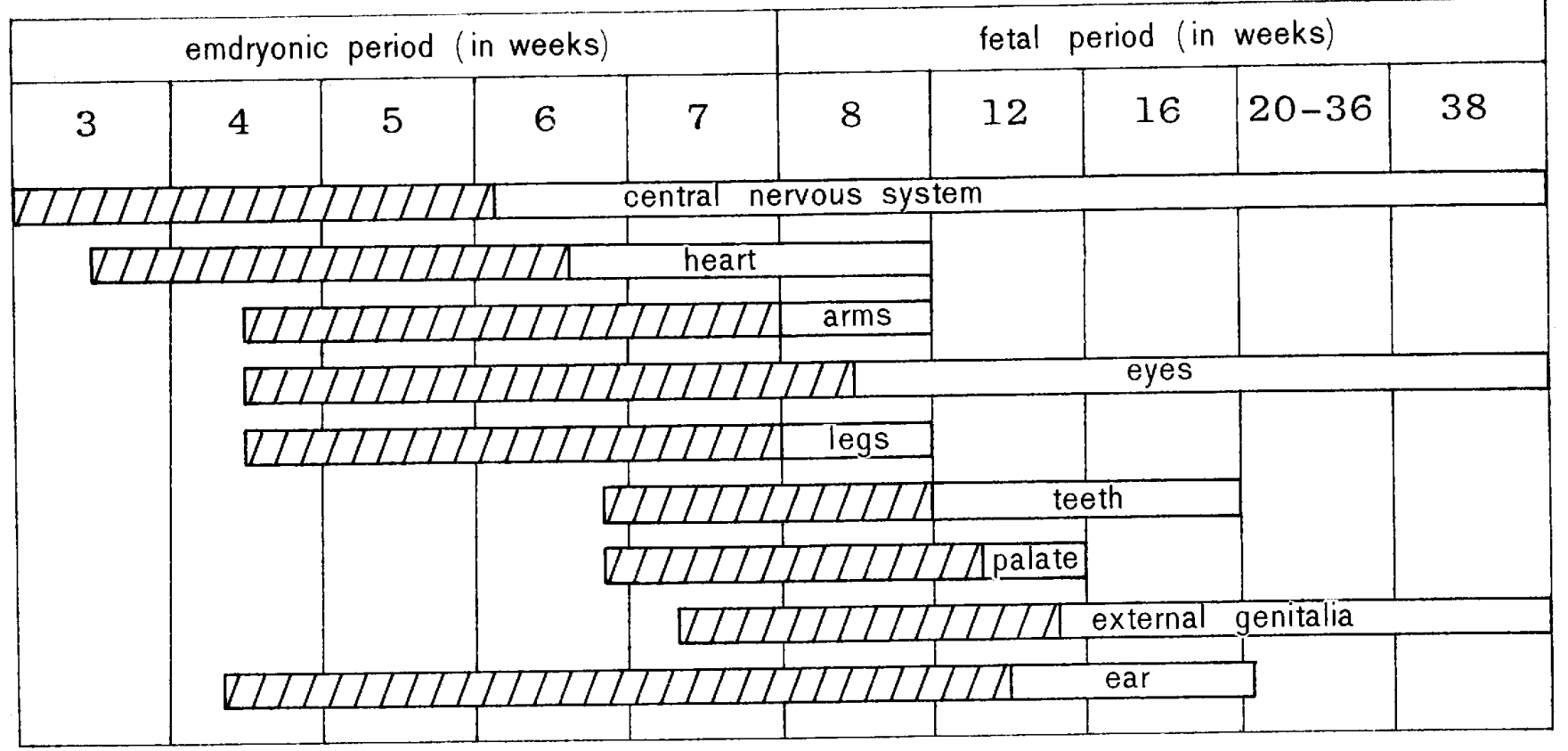

Fig. 1 Scheme of the sensitive or critical periods in human development. $\mid I / I$ denotes highly sensitive periods, $\square$ indicates stages that are less sensitive to teratogens. (Moore)

CRS were infected by rubella, it is logical to assume that the rubella infection in utero influenced the permanent dentition of 12 year old children with CRS accompanying the hearing difficulties.

When comparing the CRS and Control children, the eruption rates of the maxillary canines, mandiblar second premolars, maxillary and mandiblar second molars of the CRS children are significantly lower than those of the Control children. Also, anodontia is found in all kinds of teeth in the CRS children except the first premolar; two cases of anodontia in the maxillae and 16 cases in the mandibles, i.e., more anodontia in the mandibles. That the children with CRS have higher incidence of the delayed eruption of the permanent dentition and the anodontia is considered to be very closely correlated to the authors' reports ${ }^{11}$ 14) that the head and face, especially the bigonial breadth and dental arch breadth, of the children with CRS are smaller and the retention rates of the deciduousteeth of the children with CRS are higher than the Control children.

\section{Conclusions}

In August, 1977, the investigation of the permanent teeth in children with CRS (12 years old, 55 males, 49 females : total 104) was conducted. Those children were attending a class for the hearing difficulty located in the middle south of Okinawa Island. Detailed oral examination was done and plaster models of the upper and lower dental arches and panoramic radiographs were taken.

1. Rubella virus obviously caused the disturbances of the development of the per- 
manent dentition.

2. Anodontia was found in the children with CRS and especially more in the mandibles.

3. Delayed eruption of the permanent dentition was obviously recognized in the children with CRS as with the lower eruption rates of canines, second premolars and second molars.

4. There is no significant difference in the eruption rates of central incisors, lateral incisors, first premolars and first molars between the CRS and Control children.

\section{References}

1. Gregg, N. M. : Congenital cataract following german measles in the mother, $\operatorname{Tr}$. Ophth. Soc. Australia, 3:35-46, 1941.

2. Abel, S. and Vandellen, T. R. : Congenital defects following maternal rubella, JAMA , : 1210-1212, 1949.

3. Kresky, B., Nauheim, J.S., et al. : Rubella retinitis, Am. J. Dis. Child., 113 : 305-310, 1967.

4. Rudolph, A. J., Yow, M.D., et al. : Transplacental rubella infection in newly born infants, JAMA $191: 843-845,1965$.

5. Rudolph, A.J., Singleton, E.B., et al. : Osseoas manifestations of the congenital rubella syndrome, Am. J. Dis. Child. 110:428-433, 1965.

6. Shiff, G.M., Sutherland, J.M., et al. : Studies on congenital rubella, Am. J. Dis. Child. $110: 441-443,1965$.

7. Cooper, L.Z., Ziring, P.R., et al. : Rubella, Am. J. Dis. Child. $118: 18-29,1969$.

8. Desmond, M.M., Montgomery, J.R., et al. : Congenital rubella encephalitis, Am. J. Dis. Child. $118: 30-31,1969$.

9. Menser, M.A., Dorman, D.C., et al. : Congenital rubella, Am. J. Dis. Child. $118: 32-34,1969$.

10. Sakugawa, H. : An investigation of the developmental neurology in congenital rubella syndrome, Psych. Neur. Jap. 78:587-609, 1976.

11. Murakami, M. and Rokutanda, A. : On the somatological measurement of the head and face of children with congenital rubella syndrome in Okinawa, Japan, Acta Anat. Nippon 53 (6) : 435-443, 1978.

12. Murakami, M., Rokutanda, A., et al. : Growth failure of the head and face of children with congenital rubella syndrome, Acta Anat. Nippon 54 (3) : (in the press)

13. Murakami, M., Rokutanda, A., et al. : The correlation between head and face, and dental arch of children with congenital rubella syndrome, J. Kyushu Dent. Soc. 32 (5) : 660-672, 1979.

14. Murakami, M., Rokutanda, A., et al. : Statistic observations on the retained 
deciduous teeth of children with congenital rubella syndrome, J. Kyushu Dent. Soc. 32 (5) : 673-685, 1979.

15. Moore, K.L. : Before we are born, Basic embryology and birth defects, W.B. Saunders Company, Philadelphia, 1974, 88-94.

16. Langman, J. : Medical embryology, The Williams \& Wilkins Company, Baltimore, $1969,79-80$.

17. Orban, B.J. : Oral histology and embryology, The C.V. Mosby Company, St. Louis, $1957,34-54$.

18. Provenza, D. V. : Oral histology inheritance and development, J. B. Lippincott Company, Philadelphia, 1964, 111-117. 


\title{
先天性風疹症候群児 (12才) 永久曾の Dentition について
}

\author{
九州歯科大学解剖学講座 (主任：山田 博教授) \\ 村上守良・六反田篤・伊東励 \\ 九州歯科大学口腔衛生学講座（主任：佐伯栄一教授) \\ 伊波富夫 \\ 名 取 有 三
}

1977年 8 月, 沖縄本島中南部にある難聴学級に在籍す 万先天性風装症候群児（12才）104名（男55名，女49名） を対象として，日腔診查，上下歯列の印象採得およびX 線撮影を行ない永久菌の生歯状況について正常対照群児 と比較検討した結果，次のでとき結論を得た。

1. 風绦ウイルスは永久歯の生歯に明らかに障害を及ぼ
すものである。

2. 先天性風疹症候群児において無䨑症が認められ上敄 より下顎に多く発現する.

3. 先天性風疹症候群児における大歯, 第 2 小罒菌およ び第 2 大臼歯の萌出率は正常児より低く，明らかに萌 出遅延が認められた。 